\title{
Surveillance of phlebotomine fauna and Didelphis marsupialis (Didelphimorphia: Didelphidae) infection in an area highly endemic for visceral leishmaniasis in Colombia
}

\author{
Marlon Mauricio Ardila1,2, Lina Carrillo-Bonilla ${ }^{3,4}$, Adriana Pabón ${ }^{5}$, Sara M. Robledo 3 \\ ${ }^{1}$ Grupo Biodiversidad del Caribe Colombiano, Facultad de Ciencias Básicas, Universidad del \\ Atlántico, Barranquilla, Colombia \\ ${ }^{2}$ Ciencia, Educación y Tecnología, CETIC, Facultad de Ciencias Básicas, Universidad del \\ Atlántico, Barranquilla, Colombia \\ ${ }^{3}$ Programa de Estudio y Control de Enfermedades Tropicales, PECET, Facultad de Medicina, \\ Universidad de Antioquia, Medellín, Colombia \\ ${ }^{4}$ Facultad de Ciencias Agrarias, Universidad de Antioquia, Medellín, Colombia \\ ${ }^{5}$ Grupo Malaria, Facultad de Medicina, Universidad de Antioquia, Medellín, Colombia
}

Introduction: The study of the interaction between the parasite, the vector and the mammalian hosts, including man, allows to understand the behavior of the leishmaniases. Objective: To determine the presence of Lutzomyia species and to detect the Leishmania infection in Didelphis marsupialis in an endemic area for visceral leishmaniasis.

Materials and methods: Phlebotomine fauna and individuals of $D$. marsupialis were collected with CDC and Tomahawk ${ }^{\mathrm{TM}}$ traps, respectively. The species of Lutzomyia were identified using the Young and Duncan key (1994). Ear and tail biopsies and blood samples from $D$. marsupialis were taken to identify the Leishmania species by amplifying a fragment of the gene associated with the $70 \mathrm{kD}$ heat shock protein.

Results: Seven Lutzomyia species were identified: Lu. evansi, Lu. gomezi, Lu. panamensis, Lu. dubitans, Lu. cayennensis cayennensis, Lu. rangeliana and $L u$. trinidadensis. The first three species have epidemiological importance in Colombia because of their implications in the transmission of the Leishmania parasite. Sixty-five tissue samples from 19 D. marsupialis individuals were negative for Leishmania spp.

Received: 23/06/17 Accepted: $16 / 09 / 18$

Published: $17 / 09 / 18$

\section{Citation:}

Ardila MM, Carrillo-Bonilla L, Pabón A, Robledo SM Surveillance of phlebotomine fauna and Didelphis marsupialis (Didelphimorphia: Didelphidae) infection in an area highly endemic for visceral leishmaniasis in Colombia. Biomédica. 2019;39:252-64. https://doi.org/10.7705/biomedica.v39i2.3905

Corresponding author:

Sara M. Robledo, PECET, Facultad de Medicina, Universidad de Antioquia, Calle $70 N^{\circ} 52-21$, Medellín, Colombia

Telephone: (574) 2196503

sara.robledo@udea.edu.co

Author contributions:

Marlon Mauricio Ardila: Conception, design, implementation, sample and data acquisition, analysis and interpretation of results, and writing of the manuscript

Lina Carrillo-Bonilla: Design, execution, analysis and interpretation of results, and writing of the manuscript Adriana Pabón: Conception, design, analysis and interpretation of results, and writing of the manuscript Sara María Robledo: Analysis of results and manuscript writing

\section{Funding:}

This work was supported by the Universidad de Atlántico through the Vicepresidency of Research, Extension, Social Projection and University Welfare and by Colciencias (CT-695-2014).

Conflicts of interest:

The authors have no conflicts of interest to declare.
Conclusions: The presence of the Lutzomyia species that have been identified as vectors for Leishmania inside and around houses in the village of El Bledo, in El Carmen de Bolívar represents a risk of infection. Furthermore, the presence of $L u$. panamensis is reported for first time in El Carmen de Bolívar in Colombia. Although the lack of detection of Leishmania spp. in $D$. marsupialis samples may suggest that $D$. marsupialis does not play an important role in the transmission cycle of Leishmania in this region, it is necessary to carry out further longitudinal studies to confirm this hypothesis.

Keywords: Psychodidae; Lutzomyia; Didelphis; Leishmania spp.; leishmaniasis, visceral; polimerase chain reaction.

Vigilancia de la fauna flebotomínea e infección de Didelphis marsupialis (Didelphimorphia: Didelphidae) en un área de alta endemia de leishmaniasis visceral en Colombia

Introducción. El estudio de la interacción entre el parásito, el vector y los huéspedes mamíferos, incluido el hombre, permite entender el comportamiento de la leishmaniasis. Objetivo. Determinar la presencia de especies del género Lutzomyia y detectar la infección por Leishmania spp. en Didelphis marsupialis en un área endémica de leishmaniasis visceral. Materiales y métodos. Se recolectaron flebotomíneos y $D$. marsupialis con trampas CDC y Tomahawk ${ }^{\mathrm{TM}}$, respectivamente. Las especies de Lutzomyia se identificaron usando la clave de Young y Duncan, 1994. Se tomaron biopsias de oreja, cola y muestras de sangre de $D$. marsupialis para diagnosticar Leishmania spp. mediante la amplificación de un fragmento del gen de la proteína de choque térmico de $70 \mathrm{kD}$.

Resultados. Se identificaron siete especies de Lutzomyia: Lu. evansi, Lu. gomezi, Lu. panamensis, Lu. dubitans, Lu. cayennensis cayennensis, Lu. rangeliana y Lu. trinidadensis. Las tres primeras especies son reconocidas como vectores en el país por estar implicadas en la transmisión de Leishmania spp. En total, 65 muestras de tejidos de oreja, cola y de sangre provenientes de 19 D. marsupialis fueron negativas para Leishmania spp. en la PCR-HSP70.

Conclusiones. La presencia de flebotomíneos con importancia epidemiológica en la zona evaluada representa un riesgo de transmisión. Asimismo, Lu. panamensis es reportada por primera vez en El Bledo (Carmen de Bolívar). La ausencia de Leishmania spp. en D. 
marsupialis podría sugerir que esta especie no tiene un papel importante en el ciclo de transmisión de Leishmania en la vereda El Bledo, por lo que es necesario profundizar en estudios longitudinales para corroborar esta hipótesis.

Palabras clave: Psychodidae; Lutzomyia; Didelphis; Leishmania spp.; leishmaniasis visceral; reacción en cadena de la polimerasa.

Leishmaniasis is an infectious disease caused by metaxenic trypanosomatid parasites belonging to the Leishmania genus Ross, 1903 (Euglenozoa, Kinetoplastea: Trypanosomatidae). These parasites require two hosts in nature: A mammalian host which acts as a reservoir of the infectious agent and an insect host which acts as a biological vector responsible for the transmission (1-3). The domestic dog is the proven reservoir of Leishmania infantum (syn. L. chagasi), the etiologic agent of visceral leishmaniasis $(2,4)$, while Didelphis marsupialis Linnaeus, 1758, (commonly named opossum) has been implicated as the most likely wild reservoir of this Leishmania species (5-9). In turn, the biological vectors are insects belonging to the phlebotomine group (Diptera: Psychodidae, Phlebotominae), Lutzomyia species (França, 1924 ) in the New World (America) and Phlebotomus species (Rondani \& Berté, 1840) in the Old World (Africa, Asia and Europe) vector $(1,3)$.

Leishmaniasis is present in tropical and subtropical areas of the world and still endemic in 98 countries on five continents (10) but only notifiable in 33 countries (11). It is estimated to affect about 12 million people worldwide (12) and approximately 1.3 million new cases are registered each year, of which 300,000 correspond to visceral leishmaniasis and one million cases correspond to cutaneous leishmaniasis (11).

In each region, leishmaniasis has different clinical manifestations as well as ecological characteristics (parasites, vectors, reservoirs, and transmission scenarios), making more complex the study of this parasitic disease $(1,13)$. In Colombia, 7,900 cases of leishmaniasis were recorded in 2015 of which 7,777 (98.4\%) were cutaneous leishmaniasis, $108(1.4 \%)$ mucosal leishmaniasis and $15(0.2 \%)$ visceral leishmaniasis (14). Ten of the 15 cases of visceral leishmaniasis diagnosed in the country occurred in the department of Bolívar, and eight of these were reported in the municipality of El Carmen de Bolívar. Thus, this region has the highest incidence of visceral leishmaniasis in the country. Despite the efforts of health agencies, the number of cases continues to increase largely due to the lack of knowledge of key factors in disease transmission, such as the presence of wild reservoirs.

Given that El Carmen de Bolívar is an endemic area for visceral leishmaniasis, the objectives of this study were to determine the presence of Lutzomyia species and to detect Leishmania spp. infection in D. marsupialis in and around houses in El Carmen de Bolívar, Colombia. Importantly, this will contribute to the knowledge about the presence, composition, and distribution of phlebotomine fauna and wildlife reservoirs involved in the transmission cycle in this region.

\section{Materials and methods}

\section{Study area}

The study was conducted in the village of El Bledo ( $09^{\circ} 45^{\prime} 38.0^{\prime \prime}-\mathrm{W}$ 075 10'19.1'), El Carmen de Bolívar municipality (Bolívar, Colombia), 251 m.a.s.I. El Bledo has 48 houses and 204 inhabitants: 46 children are under 5-years old, 152 persons are 5 to 61-years old and six people are more than 62 years-old (Secretaría de Salud del Departamento de Bolívar, unpublished 
data). Three houses built of adobe walls and palm roofs were selected for sampling. A case of visceral leishmaniasis in a child under five years was reported in one of these houses.

\section{Sampling of phlebotomine specimens}

Four samplings were conducted from October to December, 2014, with three incandescent-light CDC (Centers for Disease Control and Prevention) traps in each evaluated ecotope, during three consecutive nights from 6:00 p.m. to 6:00 a.m., in the domestic (defined as the whole area within the dwelling), peridomestic (the surroundings of the house) and sylvatic ecotopes (the entire forest area), with a sampling effort of 1,296 total hours. The collected insects were killed with cold water and placed in labeled Eppendorf vials with $70 \%$ alcohol and stored for subsequent separation and taxonomic identification.

\section{Sampling of wild mammals}

Ten Tomahawk ${ }^{\mathrm{TM}}$ galvanized steel traps were placed $(66.04 \mathrm{~cm} \mathrm{x}$ $22.86 \mathrm{~cm} \times 22.86 \mathrm{~cm}$ ) (Model 205, medium) for three consecutive nights in peridomestic and sylvatic ecotopes, with a sampling effort of 1,440 total hours. Sardine, papaya, banana or boiled egg were used as bait.

The captured wild mammals were anesthetized with a 1:9 mixture of ketamine-xylazine, administered intramuscularly. Tissue biopsies were collected from the tail and from one ear of each individual. Additionally, a blood sample from the tail of each individual was collected.

Biopsy areas were disinfected with $70 \%$ alcohol and sterile scissors (one per sample and per animal) were used. When the procedure was finished, Curagan $^{\mathrm{TM}}$ (Novartis, Bogotá, Colombia) was applied to avoid infections or myiasis. The cut in the ear was triangular and always in the same ear with the intention of recognizing the recaptured animals.

In turn, the blood samples were taken in MiniCollect ${ }^{\mathrm{TM}}$ tubes of $1 \mathrm{~mL}$ with EDTA. One drop was deposited on a filter paper $(1 \mathrm{~cm}$ diameter). The animals were released after recovering from the effects of anesthesia. All samples were stored immediately in a vial with ethanol and labeled for subsequent DNA extraction and PCR amplification.

\section{Identification of phlebotomines}

The insects were examined under a stereoscope (Leica EZ4 Microsystem ${ }^{\mathrm{TM}}$, Mannheim, Germany) and phlebotomines were separated from other insects, rinsed with $10 \% \mathrm{KOH}$, dried by evaporation and mounted permanently using a mixture of xylene and Canada balm. Taxonomic identification was achieved following the Young and Duncan key (15) using a conventional microscope (Zeiss ${ }^{\mathrm{TM}}$, Buenos Aires, Argentina).

\section{DNA extraction}

The extraction of DNA from ear, tail and blood samples was performed with the DNeasy Blood \& Tissue Kit ${ }^{\mathrm{TM}}$ (Qiagen Genomic Inc., California, USA), following the manufacturer's instructions. For blood samples impregnated on filter paper, Chelex protocol 100X and heating was employed (16). The concentration of total DNA was quantified using a NanoDrop $1000^{\mathrm{TM}}$ (Thermo Scientific, Massachusetts, USA). 


\section{Polymerase chain reaction (PCR) for the amplification of a Heat Shock Protein 70 kD (hsp70) gene fragment}

Primers that amplify a gene fragment coding for the $70 \mathrm{kDa}$ heat shock protein (Hsp70-P4) (240 pb): Forward 5'GGA CGA GAT CGA GCG CAT GGT3' and reverse 5'TCC TTC GAC GCC TCC TGG TTG3' were used (17). We run $1 \%$ agarose gels to check the integrity of the DNA. When tissues are used it is necessary to determine the integrity of one constitutive DNA, for example, the $\beta$-actin protein, for the sturdiness of PCR. As a positive control, a pool of $L$. donovani and $L$. infantum DNA was used.

PCR was performed in a C1000TM BioRad thermocycler ${ }^{\mathrm{TM}}$ (BioRad, California, USA) under the following conditions: An initial heating at $95^{\circ} \mathrm{C}$ for $3 \mathrm{~min}$ followed by 32 cycles (denaturation at $94{ }^{\circ} \mathrm{C}$ for $30 \mathrm{~s}$, alignment at 63 ${ }^{\circ} \mathrm{C}$ for $1 \mathrm{~min}$ and extension at $72{ }^{\circ} \mathrm{C}$ for $1 \mathrm{~min}$ ) and a final incubation at $71^{\circ} \mathrm{C}$ for 9 min for extension of PCR products.

Each PCR mixture was performed in a final volume of $20 \mu \mathrm{L}$ with $2 \mu \mathrm{L}$ of target DNA and $18 \mu \mathrm{L}$ of reaction mixture containing $2 \mu \mathrm{L}$ of PCR buffer 10X (10X Taq buffer with KCl) (Fermentas ${ }^{\mathrm{TM}}$, Thermo Fisher Scientific, Massachusetts, USA), $1 \mu \mathrm{L}$ of deoxyribonucleotide triphosphates (dNTP), 1.2 $\mu \mathrm{L} \mathrm{MgCl}, 0.4 \mu \mathrm{L}$ of each primer, $0.2 \mathrm{U} / \mu \mathrm{L}$ Taq DNA polymerase (Fermentas ${ }^{\mathrm{TM}}$, Thermo Fisher Scientific, Massachusetts, USA), $0.1 \mu \mathrm{L}$ dimethyl sulfoxide (DMSO), and $12.7 \mu \mathrm{L}$ miliQ sterile water. A positive control $(18 \mu \mathrm{L}$ reaction mixture $+2 \mu \mathrm{L}$ of control DNA template) was included. Dilutions of 1:5, 1:25 and 1:125 were made from the samples that exhibited PCR inhibition and 2 $\mu \mathrm{L}$ from the positive DNA control were added to each reaction.

\section{Electrophoresis and visualization of the amplification products}

The amplification products obtained by PCR were subjected to horizontal electrophoresis ( $40 \mathrm{~min} / 110 \mathrm{~V}$ ) in $2 \%$ agarose gels in TBE $1 \mathrm{X}$ buffer and ethidium bromide $(0.5 \mu \mathrm{g} / \mu \mathrm{L})$. For this, $8 \mu \mathrm{L}$ PCR of product were mixed with $2 \mu \mathrm{L}$ of loading buffer. The PCR products were visualized with an ultraviolet transilluminator (Bio-Rad, California, USA). Samples were considered positive when a $240 \mathrm{bp}$ band was visualized using as reference the PCR positive control and a 1000 pb DNA Ladder marker ${ }^{\mathrm{TM}}$ (Fermentas ${ }^{\mathrm{TM}}$, Thermo Fisher Scientific, Massachusetts, USA) (18).

\section{Statistical analysis}

The number of phlebotomine individuals according to the species, environment and sampling period was evaluated. The Shapiro-Wilk W test was applied in order to determine if the data conformed to a normal distribution. This was done using the PAST program, version 2.11 (19). To detect statistical differences in the comparison of wealth and abundance among different sampling points (environment-sampling period), the one-way ANOSIM test was performed. Lastly, the frequency of the species of wild mammals captured was determined.

\section{Ethical considerations}

The study was approved by the Ethics Committee of the Universidad del Atlántico, Barranquilla, Colombia (June 11, 2014). 


\section{Results}

A total of 3,090 individuals were collected using CDC incandescent light traps: 2,052 (66.3\%) females and 1,038 (33.6\%) males (not normally distributed, Shapiro-Wilk test). All specimens corresponded to Lutzomyia spp. (table 1). Lutzomyia evansi (verrucarum group Theodor 1965) was the most representative species followed by Lu. gomezi, Lu. dubitans (migonei group Theodor, 1965), Lu. panamensis (Psychodopygus genus Mangabeira, 1941), Lu. cayennensis cayennensis (Mycropygomyia genus, Barreto, 1962), and two species corresponded to $L u$. rangeliana (ungrouped species) and Lu. trinidadensis (oswaldoi group, Theodor, 1965). One-hundred and one phlebotomines corresponding to 85 female and 16 male individuals remained without identification and therefore they were recorded as Lutzomyia spp.

Table 1. Diversity and abundance of phlebotomines collected in the village of El Bledo, El Carmen de Bolívar (Bolívar)

\begin{tabular}{|c|c|c|c|c|c|c|c|c|c|c|c|c|}
\hline \multirow{2}{*}{ Species } & \multicolumn{3}{|c|}{ D } & \multicolumn{3}{|c|}{ PD } & \multicolumn{3}{|c|}{$\mathbf{S}$} & \multirow{2}{*}{ 우 } & \multirow{2}{*}{ ه } & \multirow{2}{*}{ Total (\%) } \\
\hline & 우 & वיד & Total & 우 & ه & Total & 우 & ד & Total & & & \\
\hline Lu. evansi* & 439 & 107 & 546 & 594 & 198 & 792 & 379 & 196 & 575 & 1,412 & 501 & $1,913(61.91)$ \\
\hline Lu. panamensis* & 16 & 7 & 23 & 53 & 20 & 73 & 42 & 6 & 48 & 111 & 33 & $144(4.66)$ \\
\hline Lu. dubitans & 88 & 13 & 101 & 23 & 14 & 37 & 18 & 17 & 35 & 129 & 44 & $173(5.60)$ \\
\hline Lu.c. cayennensis & 2 & 1 & 3 & 3 & 0 & 3 & 2 & 0 & 2 & 7 & 1 & $8(0.26)$ \\
\hline Lutzomyia sp. & 46 & 3 & 49 & 23 & 9 & 32 & 16 & 4 & 20 & 85 & 16 & $101(3.27)$ \\
\hline Total & & 971 & & & 1,2 & & & 859 & & 2,052 & 1,038 & 3,090 \\
\hline
\end{tabular}

D: Domestic; PD: Peridomestic; S: Sylvatic; 우: Female; ơ': Male

* Species with epidemiological background

Lutzomyia evansi was also the most abundant species in the three ecotopes sampled during the study. The peridomestic ecotope provided the greatest wealth and abundance with 1,260 individuals grouped into seven species. However, no statistically significant differences were observed in terms of abundance and wealth between sampling periods and ecotopes evaluated ( $p=0.4872$, ANOSIM test).

Overall, 19 individuals of $D$. marsupialis (11 males and 8 females) were captured that corresponded to 12 adults and 7 juvenile specimens. The largest catches $(n=15)$ were made in the peridomestic ecotopes. Sixty-four samples were taken in total: Ears $(n=19)$, tails $(n=16)$, and blood $(n=13)$ collected in MiniCollect ${ }^{\mathrm{TM}}$ tubes with $1 \mathrm{~mL}$ of EDTA and 16 blood samples collected on filter paper. All samples were negative for Leishmania spp. PCR inhibition was confirmed in one sample (figure 1). The inhibition was neutralized at a dilution of 1:125.

\section{Discussion}

El Bledo village provides the ecological conditions for maintaining the transmission cycle of leishmaniasis because most of the houses are constructed with adobe walls with roofs of palm branches that allow the vector to settle. In this work, a total of 3,090 Lutzomyia spp. individuals, distributed into seven species, were collected.

Lutzomyia evansi was the most representative species identified in the present study. This is a species commonly found in several countries in 


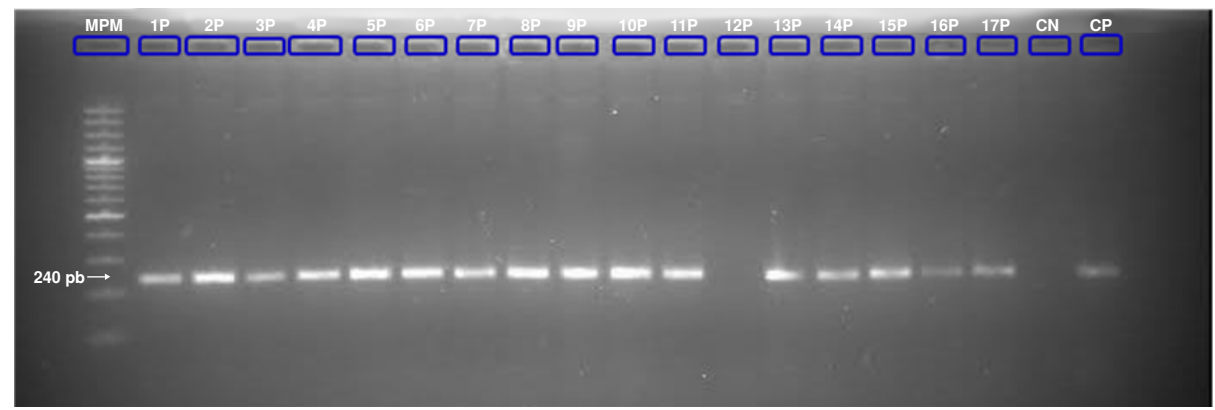

Figure 1. Hsp70 gene amplification of DNA samples extracted from ear tissues of Didelphis marsupialis mixed with a DNA positive control

MPM: Molecular weight marker (100-1000 pb); wells 1P-17P: Ear samples with DNA positive control; CN: Negative control; CP: Positive control; 240bp: Band corresponding to control amplicon

Central and South America (15), from the tropical dry forest (0-500 m.a.s.l) to the dry montane forest (500-1500 m.a.s.I) (20). In addition, Lu. evansi is the main vector of Leishmania species causing visceral leishmaniasis throughout the Colombian Caribbean region (21) and in some regions of Venezuela (22). It is also associated with the transmission of $L$. braziliensis, one of the etiologic agents of cutaneous leishmaniasis in South America (23). Furthermore, Lu. evansi was recognized for the first time as the main vector of L. chagasi (syn. L. infantum) in San Andrés de Sotavento (Colombia, $9^{\circ} 08^{\prime} 43 " \mathrm{~N}$ - 75॰30'31"O) (21).

Lutzomyia gomezi was the second most significant species in this study, consistent with other work done in Sincelejo (Sucre) by Lambraño, et al. (24). It has been found infected with $L$. panamensis in Colombia by Santamaría, et al. (25) and it is the proven vector of L. panamensis in Panamá (26), although it has also been found infected with $L$. braziliensis in Venezuela $(27,28)$ and recognized as a vector of Leishmania species that cause cutaneous leishmaniasis in Colombia and in other regions in South America (3). It has been reported in Venezuela, Bolivia, Ecuador, Perú, French Guiana, southern Brazil, Nicaragua, Costa Rica, El Salvador, Guatemala, Honduras, México, Panamá, Trinidad and Tobago, and Colombia $(15,29)$.

Lutzomyia gomezi has been registered in the municipality of El Carmen de Bolívar (department of Bolívar, Colombia) (30). Interestingly, its wide distribution lies in its ability to be an eclectic species, allowing greater ability to colonize in completely degraded environments. This facilitates access to various food resources, among these, a variety of mammals including humans (31).

Lutzomyia panamensis $(n=144)$ corresponded to the fourth most abundant species of all phlebotomines collected in the present study. However, it is the third in epidemiological importance, being the most abundant reported by Pérez, et al. (32). Lutzomyia panamensis has a wide distribution in Central and South America countries, including Colombia (5). Furthermore, it is considered anthropophilic and a vector of the etiologic agents of cutaneous leishmaniasis in different regions of Colombia, Panamá, and Venezuela $(25,26,33)$.

Lutzomyia c. cayennensis is a phlebotomine that has a wide distribution in Central and northern South America (15). It has been reported in the department of Bolívar (Colombia), mainly in El Carmen de Bolívar (30) and is often found in foci of visceral leishmaniasis, where Lu. evansi and Lu. longipalpis predominate (34). Although the abundance recorded in this study was low $(n=8,0.26 \%)$, these individuals were collected in the three 
environments evaluated. The females of this species are characterized by feeding on the blood of reptiles and perching on the walls of the houses, which preferably give them greater contact with lizards, a behavior that is observed only in the Caribbean region $(35,36)$. However, at high densities, they could also attack humans (3). Lutzomyia c. cayennensis has been found naturally infected with trypanosomatids in Ovejas (Sucre, Colombia) (35) and in Venezuela $(28,37)$.

The medical significance of the Lu. dubitans species found in this study is unknown because it has not been identified as a vector (38).

Lutzomyia rangeliana and $L u$. trinidadensis were the phlebotomine species with the lowest recorded abundance, each of them with a single individual $(0.03 \%)$. The first species is restricted to Venezuela, Trinidad and Tobago, Panamá, and Colombia. Lutzomyia trinidadensis has a wide geographical distribution in Central America and northern South America (15) and it is associated with the distribution of different species of lizards (36). To date, the role these species play in Leishmania spp. transmission remains in discussion. However, in Venezuela, these species were found positive for flagellates $(37,39)$. It has also been related to visceral leishmaniasis foci where $L u$. evansi usually predominates $(24,32,34,35,40)$.

There were no significant differences found when the diversity and abundance among the different environments were evaluated (domestic, peridomestic and sylvatic ecotopes) and then compared with the sampling period. This could be due to the fact that the distance between each trap was approximately 20 meters, which is perhaps very short. Therefore, we recommend using a greater distance between the traps to see if the pattern seen in the present study is maintained. Nevertheless, the captured species cannot be suspected as vectors in the study area, because vectorial capacity tests such as natural infection were not performed among the captured species. On the other hand, one cause of the results could be the fact that in urban or suburban areas there is not one a well-defined separation between domestic, peridomestic and sylvatic ecotopes.

In Colombia, although limited, here are some studies related to the identification of Leishmania spp. in domestic and wild mammals. Dogs are animals of companionship and surveillance in the different human activities in the forest (mainly hunting and logging), and therefore they have a high degree of exposure to vectors. The dog has been identified as an important reservoir because canines are in permanent contact with humans and have been involved in the maintenance of the transmission cycle for $L$. infantum (syn. $L$. chagasi) (2). However, among vertebrate host species related to cutaneous leishmaniasis, the domestic dog has been the centre of controversy and there is a lack of consensus regarding their role as reservoir $(2,41)$. In Colombia, few studies have been carried out on the role of dogs in the cycle of $L$. panamensis and $L$. braziliensis, two of the major species of Leishmania spp. in the country. Santaella, et al. (42) and Vélez, et al. (43) described a natural infection with $L$. guyanensis, $L$. panamensis and $L$. braziliensis in symptomatic dogs. The finding of dogs infected with Leishmania spp. shows their susceptibility but it is not enough to implicate dogs as reservoirs and, therefore, more and stronger evidence is needed.

Similarly, the role played by wild mammals in the different cycles of Leishmania spp. transmission is still unknown. From the epidemiological point of view, the first wild mammals described with natural infection in Colombia 
were D. marsupialis in El Callejón (Cundinamarca) $(5,6), D$. marsupialis and Proechimys canicollis in San Andrés de Sotavento (Córdoba) $(7,8)$, and $D$. marsupialis and P. canicollis in Colosó (Sucre) (8). The presence of corrals and wild or cultivated vegetation around houses favor the attraction of synanthropic mammals that could be potential reservoirs to Leishmania species.

In the present study, only $D$. marsupialis $(n=19)$ were captured around houses, although none of them were positive for Leishmania. They have a wide geographical distribution from northwestern México to Bolivia, coinciding with cutaneous leishmaniasis and visceral leishmaniasis foci, making this species a highly suspicious reservoir. In Colombia, this species is found from 0 to 2,500 ma.s.I. It adapts easily to different environments such as wet and dry forests. They can even inhabit urban and suburban areas (44), although they may or may not have direct contact with humans. Didelphis marsupialis is identified as a bioindicator species for highly intervened environments, which makes them easily adaptable that can survive in humanmodified environments and occupy abandoned spaces $(9,45)$. Thus, they are considered highly specialized species when the environment is changed. Because D. marsupialis is a species with nocturnal and nomadic behaviors, it is in constant exposure to vectors and, therefore, may serve as a bridge between vectors and humans in the sylvatic and peridomestic transmission cycles. It can even function as a probable bridge between endemic and non-endemic areas for leishmaniasis $(9,44)$. This finding, in association with the presence of recognized vectors such as Lu. evansi, Lu. gomezi and Lu. panamensis around houses, may increase the risk factor for the residents of a given community $(2,21,23,25,33,38,46)$.

The absence of positive animals suggests that there are other factors that affect the dynamics of this parasite infection, particularly in a highly endemic area for visceral leishmaniasis such as El Carmen de Bolívar. Furthermore, $D$. marsupialis is the suspected reservoir of both cutaneous leishmaniasis and visceral leishmaniasis foci in Colombia, Brazil, Venezuela, and in French Guiana, including Leishmania species not pathogenic to humans $(5-9,47)$.

The captured animals did not show skin lesions suggestive of cutaneous leishmaniasis and their skin and blood samples were negative for the parasite. This negative result might be explained by i) the relatively short timing of capture of mammals that led to a low number of individuals evaluated, ii) not including other tissues in the sampling such as liver, spleen, bone marrow, and/or lymph node that could favor the detection of visceralized species such as $L$. infantum, and iii) the fact that Didelphis marsupialis has not been previously identified as a reservoir of Leishmania spp. in the studied area, which suggests that other wild mammals may be participating in the natural cycle of transmission of Leishmania spp. in this area. Supportive of our findings, De Lima, et al. (48) did not find D. marsupialis naturally infected with Leishmania spp. However, new samples with a more complex experimental design are needed to test the hypothesis that other wild animals participate in the cycle of transmission.

The present study cannot rule out this species as a reservoir for not revealing detectable infection in a determined moment by PCR. This is because the dynamics between wild hosts and parasites are complex, leading to a plethora of manifestations such as behavioral changes in the host (49). The monitoring for this group of mammals must be continuous, especially in highly endemic areas. 
At the present, PCR is a highly sensitive technique and is used in epidemiological studies of leishmaniasis for the detection and identification of Leishmania species DNA in samples from patients, vectors, and reservoirs $(25,50,51)$. Using PCR to detect the presence of the $h s p 70$ gene as a molecular marker increases sensitivity to nearly $100 \%$ compared with blood cultures and xenodiagnosis (transmissibility), while the use of the gold standard allows to determine whether a mammal may be considered as a reservoir over other methods such as microscopy, Montenegro skin test (52), and serological tests (53).

This occurs because PCR directly tests the presence of the parasitic DNA in the host sample, regardless of the immune status of the mammalian host (54). Moreover, amplifying the $h s p 70$ gene with a series of gene-specific primers increases the sensitivity of parasite detection because this gene has the highest resolution over other molecular markers such as internal spacers of the ribosomal RNA transcription (ITS- rRNA), the 7SL (spliced leader) RNA, and DNA from the kinetoplast (51). It also allows the detection of genetic variability in molecules associated with immunological processes and has a high probability of being detected due to its very high number of copies $(12,52,55-57)$.

This study represents an approximation to the phlebotomine fauna in El Bledo village, where three epidemiologically important species were reported: Lu. evansi, Lu. gomezi and Lu. panamensis. Additionally, although these species were identified in the three ecotopes evaluated, they were mainly found around the houses, which correlates with the places where the largest number of individuals of $D$. marsupialis were also collected.

The phlebotomine species collected in this work were not evaluated for the presence of Leishmania parasites. Thus, further studies of natural infection in the phlebotomine species with known epidemiological backgrounds are needed in order to understand the full manifestation of the disease at any given time and to include all the members of the eco-pathogen complex (vector-parasite-host).

This study reports the presence of $L u$. evansi inside the houses and its surroundings, indicating that the village of El Bledo could be an area for transmission of visceral leishmaniasis, which exacerbates the public health problem in that region. Interestingly we found several synanthropic Lutzomyia species in one small area. In addition, this study reports for the first time the presence of Lu. panamensis in El Carmen de Bolívar, thus expanding its geographical distribution throughout the department of Bolívar (Colombia).

This is the first study conducted in the municipality of El Carmen de Bolívar (Bolívar) assessing the natural infection of Leishmania spp. in synanthropic mammals and opening the way to new investigations for the discovery of potential reservoirs of Leishmania spp. Although the presence of the parasite was not detected in the specimens sampled, it is important to continue with this type of study to ensure that $D$. marsupialis is not part of the transmission cycle of Leishmania (at least in El Bledo village) and to identify other wild mammals that could act as potential reservoirs of Leishmania spp.

Implementation of continuous monitoring and conducting all appropriate protective measures, mainly at the level of vector control in the intradomicile environments, by public health institutions is very important. If in the evaluated area the parasite is circulating amongst domestic or other mammals, the domestic or peridomestic vector transmission may establish a new focus of leishmaniasis transmission in Colombia. 


\section{Acknowledgments}

The authors would like to thank the Unidad de Entomología of the Secretaría de Salud, District of Barranquilla; the Unidad de Entomología of the Laboratorio de Salud Pública del Departamento de Bolívar, and the Secretaría de Salud de Bolívar for providing field logistics. The authors would also like to thank the Laboratorio de Entomología of the Secretaría de Salud, Departmento de Sucre, for their help in the identification of the phlebotomines. The authors would also like to thank B. Karman for his review of the English language. Finally, the authors would like to thank the community of El Bledo for the support provided during the samplings.

\section{References}

1. Vélez ID, Hendrickx E, Robledo SM, Agudelo S. Leishmaniosis cutánea en Colombia y género. Cad Saúde Pública. 2001;17:171-80.

https://doi.org/10.1590/S0102-311X2001000100018

2. Dantas-Torres F. The role of dogs as reservoirs of Leishmania parasites, with emphasis on Leishmania (Leishmania) infantum and Leishmania (Viannia) braziliensis. Vet Parasitol. 2007;149:139-46. https://doi.org/10.1016/j.vetpar.2007.07.007

3. Cortés LA, Fernández JJ. Especies de Lutzomyia en un foco urbano de leishmaniasis visceral y cutánea en El Carmen de Bolívar, Bolívar, Colombia. Biomédica. 2008;28:440-3. https://doi.org/10.7705/biomedica.v28i3.81

4. Romero M, Sánchez JA. Una mirada a la epidemiología y al control de la leishmaniasis zoonótica en Colombia. Biosalud. 2007;5:99-111.

5. Corredor A, Gallego JF, Tesh RB, Morales A, Ferro C, Young DG, et al. Epidemiology of visceral leishmaniasis in Colombia. Am J Trop Med Hyg. 1989a;40:480-6. https://doi.org/10.4269/ajtmh.1989.40.480

6. Corredor A, Gallego JF, Tesh RB, Peláez D, Diaz A, Montilla M, et al. Didelphis marsupialis, an apparent wild reservoir of Leishmania donovani chagasi in Colombia, South America. Trans R Soc Trop Med Hyg. 1989b;83:195.

7. Travi BL, Jaramillo C, Montoya J, Segura I, Zea A, Goncalves A, et al. Didelphis marsupialis, an important reservoir of Trypanosoma (Schizotrypanum) cruzi and Leishmania (Leishmania) chagasi in Colombia. Am J Trop Med Hyg. 1994;50:557-65. https://doi.org/10.4269/ajtmh.1994.50.557

8. Travi BL, Osorio Y, Becerra MT, Adler GH. Dynamics of Leishmania chagasi infection in small mammals of the undisturbed and degraded tropical dry forests of northern Colombia. Trans R Soc Trop Med Hyg. 1998;92:275-8.

9. Roque A, Jansen AM. Wild and synanthropic reservoirs of Leishmania species in the Americas. Int J Parasitol. 2014;3:251-62. https://doi.org/10.1016/j.ijppaw.2014.08.004

10. Ramírez C, Requena J, Puerta C. Alpha tubulin genes from Leishmania braziliensis: genomic organization, genes structure and insights on their expression. BMC Genomics. 2013;14:454-66. https://doi.org/10.1186/1471-2164-14-454

11. World Health Organization. Sustaining the drive to overcome the global impact of neglected tropical diseases: Second WHO report on neglected. Geneva: WHO; 2013.

12. Hernández C, Álvarez C, González C, Ayala M, León C, Ramírez J. Identification of six New World Leishmania species through the implementation of a High-Resolution Melting (HRM) genotyping assay. Parasit Vectors. 2014;7:501-8. https://doi.org/10.1186/s13071-014-0501-y

13. Fernández M. Eco-epidemiología de vectores de Leishmania spp. en el noreste de la Argentina (Provincia de Misiones) (tesis). Buenos Aires: Universidad de Buenos Aires; 2012.

14. Instituto Nacional de Salud. Boletín Epidemiológico Semanal, BES. Semana epidemiológica No. 52 de 2015 (27 de diciembre-02 enero). Fecha de consulta: 25 de marzo de 2016. Available in: http://www.ins.gov.co/boletin-epidemiologico/Boletn\%20 Epidemiolgico/2015\%20Boletin\%20epidemiologico\%20Semana\%2052.pdf

15. Young DG, Duncan MA. Guide to the identification and geographic distribution of Lutzomyia sand flies in Mexico, the West Indies, Central and South America (Diptera: Psychodidae). Mem Amer Ent Inst. 1994;54:1-881. 
16. Barrera S, Pérez M, Knudson A, Nicholls R, Guerra A. Genotipificación de Plasmodium falciparum por PCR múltiple por medio de los genes msp1, msp2 y glurp, en cuatro localidades de Colombia. Biomédica. 2010;30:530-8. https://doi.org/10.7705/biomedica.v30i4.291

17. Graça GC, Volpini AC, Romero GA, Oliveira MP, Hueb M, Porrozzi R, et al. Development and validation of PCR-based assays for diagnosis of American cutaneous leishmaniasis and identification of the parasite species. Mem Inst Oswaldo Cruz. 2012;107:664-74. https://doi.org/0.1590/S0074-02762012000500014

18. Sambrook J, Fritsch EF, Maniatis T. Molecular cloning: A laboratory manual. 2nd edition. New York: Cold Spring Harbor Laboratory Press; 1989.

19. Hammer $\varnothing$, Harper DA, Ryan PD. PAST: Paleontological Statistics software package for education and data analysis. Palaeontología Electrónica. 2001;4:1-9.

20. Feliciangeli MD, Arredondo C, Ward R. Phlebotomine sand flies in Venezuela: Review of the verrucarum species group (in part) of Lutzomyia (Diptera: Psychodidae) with description of a new species from Lara. J Med Entomol. 1992;29:729-44.

21. Travi BL, Vélez ID, Brutus L, Segura I, Jaramillo C, Montoya J. Lutzomyia evansi, an alternate vector of Leishmania chagasi in a Colombian focus of visceral leishmaniasis. Trans R Soc Trop Med Hyg. 1990;84:676-77.

22. Feliciangeli MD, Rodríguez N, De Guglielmo Z, Rodríguez. A. The re-emergence of American visceral leishmaniasis in an old focus in Venezuela. II. Vectors and parasites. Parasite. 1999;6:113-20. https://doi.org/10.1051/parasite/1999062113

23. Bejarano EE, Pérez A, Paternina L, Paternina M, Martínez L. Natural infection of Lutzomyia evansi (Diptera: Psychodidae) with Leishmania (Viannia) spp. in northern Colombia. Am J Trop Med Hyg. 2012;87:173.

24. Lambraño LF, Manjarrez G, Bejarano EE. Variación temporal de especies de Lutzomyia (Diptera: Psychodidae) en el área urbana de Sincelejo (Colombia). Salud Uninorte. 2012;28:191-200.

25. Santamaría E, Ponce N, Zipa Y, Ferro C. Presencia en el peridomicilio de vectores infectados con Leishmania (Viannia) panamensis en dos focos endémicos en el occidente de Boyacá, piedemonte del valle del Magdalena medio, Colombia. Biomédica. 2006;26:8294. https://doi.org/10.7705/biomedica.v26i1.1503

26. Christensen HA, Fairchild G, Herrer A, Johnson C, Young D, De Vásquez A. The ecology of cutaneous, leishmaniasis in the Republic of Panamá. J Med Entomol. 1983;20:463-84.

27. Feliciangeli MD, Rodríguez N, Bravo A, Arias F, Guzmán B. Vectors of cutaneous leishmaniasis in North-central Venezuela. Med Vet Entomol. 1994;8:317-24. https://doi.org/10.1111/j.1365-2915.1994.tb00095.x

28. Rodríguez N, Aguilar CM, Barrios MA, Barker DC. Detection of Leishmania braziliensis in naturally infected individual sandflies by the polymerase chain reaction. Trans $\mathrm{R}$ Soc Trop Med Hyg. 1999;93:47-9.

29. Bejarano EE, Estrada LG. Family Psychodidae. Zootaxa. 2016;4122:187-238. https://doi. org/10.11646/zootaxa.4122.1.20

30. Cortés L. Foco de leishmaniasis en el Hobo, Municipio de El Carmen de Bolívar, Bolívar, Colombia. Biomédica. 2006;26:236-41. https://doi.org/10.7705/biomedica.v26i1.1518

31. Contreras-Gutiérrez MA, Vélez ID, Porter C, Uribe SI. An updated checklist of Phlebotomine sand flies (Diptera: Psychodidae: Phlebotominae) from the Colombian Andean coffeegrowing region. Biomédica. 2014;34:483-98. https://doi.org/10.1590/S0120-41572014000300017

32. Pérez A, Hernández E, Bejarano EE. Lutzomyia (Diptera: Psychodidae) de la Reserva Serranía de Coraza y Montes de María, Colombia. Rev Colomb Entomol. 2008;34:98-101.

33. Duttari LC, Loaiza JR. American cutaneous leishmaniasis in Panamá: A historical review of entomological studies on anthropophilic Lutzomyia sand fly species. Parasit Vectors. 2014;7:218-28. https://doi.org/10.1186/1756-3305-7-218

34. Travi BL, Adler GH, Lozano M, Cadena H, Montoya J. Impact of habitat degradation on Phlebotominae (Diptera: Psychodidae) of tropical dry forests in Northern Colombia. J Med Entomol. 2002;39:451-6.

35. Cochero S, Anaya Y, Díaz Y, Paternina M, Luna A, Paternina L, et al. Infección natural de Lutzomyia cayennensis cayennensis con parásitos tripanosomatídeos (Kinetoplastida: Trypanosomatidae) en Los Montes de María, Colombia. Rev Cubana Med Trop. 2007;59:35-9. 
36. Johnson RN, Young DG, Butler JF, Bogaert-Diaz H. Possible determination of the vector and reservoir of leishmaniasis in the Dominican Republic. Am J Trop Med Hyg. 1992;46:282-7. https://doi.org/10.4269/ajtmh.1992.46.282

37. Bonfante R, Urdaneta R, Urdaneta I, Alvarado J, Perdomo R. Natural infection of Lutzomyia rangeliana (Ortiz, 1952) (Diptera: Psychodidae) with Leishmania in Barquisimeto, Lara State, Venezuela. Mem Inst Oswaldo Cruz. 1999;94:11.

38. Cortés L, Pérez A, Bejarano EE. Flebotomíneos (Diptera: Psychodidae) antropofílicos de importancia en salud pública en Los Montes de María, Colombia. Rev Cubana Med Trop. 2009;61:220-5.

39. Bonfante R, Urdaneta R, Urdaneta I, Alvarado J. Natural infection of Lutzomyia trinidadensis (Diptera: Psychodidae) with Leishmania in Barquisimeto, Venezuela. Mem Inst Oswaldo Cruz. 1990;85:477. https://doi.org/10.1590/S0074-02761999000100005

40. Bejarano EE, Uribe S, Rojas W, Vélez ID. Phlebotomine sand flies (Diptera: Psychodidae) associated with the appearance of urban leishmaniasis in the city of Sincelejo, Colombia. Mem Inst Oswaldo Cruz. 2002;97:645-7. https://doi.org/10.1590/S007402762002000500010

41. Reithinger R, Davies C. Is the domestic dog (Canis familiaris) a reservoir host of American cutaneous leishmaniasis? A critical review of the current evidence. Am J Trop Med Hyg. 1999;61:530-41.

42. Santaella J, Ocampo C, Saravia N, Méndez F, Góngora R, Gómez M, et al. Leishmania (Viannia) Infection in the domestic dog in Chaparral, Colombia. Am J Trop Med Hyg. 2011;84:674-80. https://doi.org/10.4269/ajtmh.2011.10-0159

43. Vélez ID, Carrillo LM, López L, Rodríguez E, Robledo SM. An epidemic outbreak of canine cutaneous leishmaniasis in Colombia caused by Leishmania braziliensis and Leishmania panamensis. Am J Trop Med Hyg. 2012;86:807-11. https://doi.org/10.4269/ajtmh.2012.11-0408

44. Aponte J. Una revisión de la biología del Didelphis marsupialis y su relación con el mal de Chagas y la leishmaniasis. Bogotá, D.C.: Uniandes; 2013. p. 94-101.

45. Cuartas CA, Marín D. Descripción de especies. En: Cuartas CA, Marín D, editores. Guía ilustrada. Mamíferos del cañón del río Porce - Antioquia. Medellín: EPM E.S.P. Universidad de Antioquia, Herbario Universidad de Antioquia, Colombia; 2014. p. 19-29.

46. Barreto M, Burbano ME, Barreto P. Nuevos registros de flebotomíneos (Diptera: Psychodidae) y triatominos (Hemiptera: Reduviidae) para Risaralda, Cauca y Valle del Cauca, Colombia. Colombia Med. 1997;28:116-22.

47. Yoshida E, Silva R, Cortez L, Corréa F. Encontro de espécie do género Leishmania en Didelphis marsupialis aurita no Estado de Sao Paulo, Brasil. Rev Inst Med Trop Sao Paulo. 1979;21:110-3.

48. De Lima H, Carrero J, Rodríguez A, De Guglielmo Z, Rodríguez N. Trypanosomatidae de importancia en salud pública en animales silvestres y sinantrópicos en un área rural del municipio Tovar del estado Mérida, Venezuela. Biomédica. 2006;26:42-50. https://doi.org/10.7705/biomedica.v26i1.1393

49. Herrera L. Una revisión sobre reservorios de Trypanosoma (Schizotrypanum) cruzi (Chagas, 1909), agente etiológico de la enfermedad de Chagas. Bol Malariol Sal Amb. 2010;50:3-15.

50. Bogild AK, Valencia BM, Espinosa D, Veland N, Ramos AP, Arevalo J, et al. Detection and species identification of Leishmania DNA from filters paper lesion impressions for patients with American cutaneous leishmaniasis. Clin Infect Dis. 2010;50:1-6. https://doi.org/10.1086/648730

51. Montalvo AM, Fraga J, Montano I, Monzote L, van der Auwera G, Marín M, et al. Identificación molecular con base en el gen hsp70 de aislamientos clínicos de Leishmania spp. en Colombia. Biomédica. 2016;36:37-44. https://doi.org/10.7705/biomedica.v36i2.2688

52. García L, Kindt A, Bermúdez H, Llanos A, De Doncker S, Arevalo J, et al. Culture independent species typing of Neotropical Leishmania for clinical validation of a PCR- based assay targeting Heat Shock Protein 70 genes. J Clin Microbiol. 2004;42:2294-7. https://doi.org/10.1128/JCM.42.5.2294-2297.2004

53. Bodini M, Vasconcelos R, Fattori K, Prado D, De Fátima A, Felix V. An investigation of Leishmania spp. in Didelphis spp. from urban and peri-urban areas in Bauru (Sao Paulo, Brazil). Vet Parasitol. 2007;150:283-90. https://doi.org/10.1016/j.vetpar.2007.09.026 
54. Reale S, Maxia L, Vitale F, Gloriosos NS, Caracappa S, Vesco G. Detection of Leishmania infantum in dogs por PCR with lymph node aspirates and blood. J Clin Microbiol. 1999;37:2931-5.

55. García AL, Téllez T, Parrado R, Rojas E, Bermúdez H, Dujardin JC. Epidemiological monitoring of American tegumentary leishmaniasis: Molecular characterization of a peridomestic transmission cycle in the Amazonian lowlands of Bolivia. Trans R Soc Trop Med Hyg. 2007;101:1208-13. https://doi.org/10.1016/j.trstmh.2007.09.002

56. Montalvo AM, Fraga J, Montano I, Monzote L, Marín M, van der Auwera G, et al. Differentiation of Leishmania (Viannia) panamensis and Leishmania (V.) guyanensis using Bccl for hsp70 PCR-RFLP. Trans R Soc Trop Med Hyg. 2010;104:364-7. https://doi.org/10.1016/j.trstmh.2009.12.002

57. van der Auwera G, Ravel C, Verweij JJ, Bart A, Schönian G, Felger I. Evaluation of four single-Locus markers for Leishmania species discrimination by sequencing. J Clin Microbiol. 2014;52:1098-104. https://doi.org/10.1128/JCM.02936-13 